\title{
Cost of Controlling Maturing Western Juniper Trees
}

\author{
JAMES A. YOUNG, RAYMOND A. EVANS, JERRY D. BUDY, AND ALLEN TORELL
}

\begin{abstract}
A cost evaluation was conducted of four alternatives for improvements on maturing western juniper (Juniperus occidentalis) woodlands. The alternatives were: (a) the use of picloram (4-amino-3,5,6-trichloropicolinic acid) to kill the trees with no further treatment, with a total cost of \$78/ha (\$31/acre); (b) picloram with sufficient limbing and/or removal of trees to allow passage of a rangeland drill for seeding at a cost of $\$ 448 / \mathrm{ha}$ (\$179/acre); (c) mechanical clearing and burning of the trees at a cost of \$595/ha (\$237/acre); and (d) wood harvesting and slash disposal at a cost of $\$ 2,080 /$ ha $(\$ 832 /$ acre $)$. The picloram and limb, mechanical, and wood-harvesting treatments provide mechanically seedable sites, but of considerably different quality in terms of ease of seeding and chances of seedling establishment. The mechanical treatment requires a large capital investment, while the wood-harvesting treatment requires a large amount of labor. Based on equivalent energy values, the wood-harvesting operation would produce a profit for the landowner who could afford to invest the labor. For a specific woodland, a combination of treatments would be most cost effective.
\end{abstract}

During the late 19th and early 20th centuries, range sites that formerly supported big sagebrush (Artemisia tridentata)/bunchgrass communities were suddenly invaded by western juniper (Juniperus occidentalis subsp occidentalis) trees (Burkhardt and Tisdale 1969, 1976; Young and Evans 1980). These stands are now in a successional stage where the trees completely dominate the site and have largely depleted the understory of competing grass and browse species. Juniper roots occupy the soil profile to the extent that the site is effectively closed for seedling establishment of desirable forage or browse species. In many stands the junipers are approaching maturity, with 150 trees/ha (60/acre); individual trees are $9.2 \mathrm{~m}(30 \mathrm{ft})$ tall and $0.5 \mathrm{~m}$ ( 20 inches) in diameter at the base (Young and Evans 1981). The tree canopies are not closed, and projected crown covers range from 36 to $45 \%$ in the stands. The density of trees on invasion sites is relatively constant, apparently reflecting an equilibrium with available environmental potential.

The purpose of this study is to evaluate alternatives for the improvement and utilization of these stands by ranchers. In other studies, either published or in progress, we have reported on why these invasion stands exist and how to prevent their occurrence. This study concerns the ranch manager's options given the existing woodlands. The study was designed for western juniper woodlands that a re owned by ranchers who are interested in enhancing forage production for livestock. Because of the power units available and the biological conditions of the stands, we did not consider chaining as a treatment. Within these constraints, the treatments evalu-

The authors are range scientists, U.S. Dep. Agr., Agr. Res. Serv., Reno, Nev. 89512 assistant professor of forestry; and formerly research associate, agricultural and resource economics, University of Nevada, Reno 89512

This is a report of cooperative research by the U.S. Dep. Agr., Res. Serv., and the Nevada Agr. Exp. Sta. Journal Series No. 494. The authors thank Carl Rimby, Lassen County Director, University of California Cooperative Extension Service, Susanville Calif., and Norris and Darrin Myers, Adin, Calif., for assistance in applying treatments and for providing the woodlands for experimentation. ated were designed with the equipment and capital available to ranchers. Although we are dealing with western juniper,which primarily inhabits northeastern California, eastern Oregon, and southwestern Idaho, the principles involved apply, within environmental limitation, to all pinyon (Pinus) (sp)/juniper woodlands.

\section{Methods and Materials}

The study area was located on Juniper Hill near Adin, in western Lassen County, California. The soils, climate, and history of juniper woodlands on the hill are given by Young and Evans (1981).

The study site consisted of approximately 32 ha $(80$ acres) of relatively uniform woodland. The average density of trees was

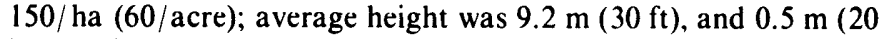
inches) in diameter at the soil level.

We evaluated four methods for the improvement of this woodland: (a) mechanical clearing and burning in preparation for seeding, (b) control of the trees with the herbicide picloram (4-amino-3,5,6-trichloropicolinic acid), (c) control of the trees with picloram followed by sufficient limbing to allow seeding, and (d) harvest of the trees for fuel wood followed by slash disposal in preparation for seeding.

The mechanical clearing was done by the ranchers using a 90 drawbar horsepower bulldozer equipped with logging canopy. We specify drawbar horsepower because modern small tractors have as much power as 10 -year-old much larger machines at the same popular designation. The trees were bunched for burning and, after initial burning, the remaining piles were rebunched for more complete burning. A rectangular piece of woodland 4 ha ( 10 acres) in area was mechanically cleared.

The picloram was applied to 0.1 ha $(0.25$ acre $)$ circular plots by three methods: (a) dripline application, (b) broadcast under the tree, and (c) area broadcast. The rate of application was a constant 14 grams per $\mathrm{m}(0.5 \mathrm{oz}$ per yard) of tree height of $10 \%$ a.i. granular herbicide. The 1979 cost of the herbicide and the cost used in this study was $\$ 4.14 / \mathrm{kg}(\$ 1.88 / \mathrm{lb})$. The plots were replicated four times.

The wood harvest plots were also 0.1 ha $(0.25$ acre $)$ and repli-

Table 1. Fuel consumption, repairs, and depreciation calculations for equipment used.

\begin{tabular}{|c|c|c|c|c|c|}
\hline \multirow[b]{2}{*}{$\begin{array}{l}\text { Equipment } \\
\text { specifications }\end{array}$} & \multirow{2}{*}{$\begin{array}{c}\text { Replace- } \\
\text { ment } \\
\text { cost }\end{array}$} & \multirow[b]{2}{*}{$\begin{array}{c}\text { Life } \\
\text { hr }\end{array}$} & \multicolumn{3}{|c|}{ Cost $/ \mathrm{hr}$} \\
\hline & & & Fuel & Repair & $\begin{array}{l}\text { Deprecia- } \\
\text { tion }\end{array}$ \\
\hline $\begin{array}{l}90 \text { h.p. track tractor } \\
\text { purchased used }\end{array}$ & $\$ 50,000$ & 12,000 & $\$ 5.00$ & $\$ 4.16$ & $\$ 3.75$ \\
\hline Chain saw & 350 & 1,000 & 0.45 & 1.75 & 0.32 \\
\hline $\begin{array}{l}\text { Woodhauling truck, } \\
3 / 4 \text { ton pickup }\end{array}$ & 7,700 & 3,000 & 2.08 & 1.17 & 2.33 \\
\hline
\end{tabular}


cated four times. A set of four wood harvesting plots was cut in 1975 and the cutting was repeated on ncw plots in 1976. All trees were cut at the soil level. Tree heights were recorded. The tree stems and limbs down to a $7.5 \mathrm{~cm}$ (3-inch) diameter were cut into $0.6-\mathrm{m}$ (2-foot) lengths and stacked for cordwood measurements. The remaining slash was piled, allowed to dry for a year, and burned. For all treatments, detailed records of labor requirements and equipment usage were maintained for use in the economic evaluations. Labor was charged at $\$ 5 /$ hour for general skill level operations and $\$ 10 /$ hour for heavy equipment operations. These labor costs are based on what the rancher could sell his labor for in the local market.

The depreciation cost for equipment used was calculated using straightline depreciation. Repair cost was calculated by the standard machinery formula of Reed and Herol (1978):

Repair cost $/ \mathrm{hr}=$ Purchase price $\times$ percent of purchase for total repairs in life

Hours of life

The percent of the purchase price allocated for repairs was $100 \%$ for the tractor, $50 \%$ for the wood-hauling truck, and $500 \%$ for the chain saw. The allocation for chain saw repairs may seem high, but is based on actual field experience.

Fuel consumption for the tractor was calculated from the Reed and Herol (1978) formula:

Fuel consumption in gallons $/ \mathrm{hr}=75 \%$ maximum $\mathrm{hp} \times .075$

The diesel fuel price was $\$ 0.22 / \mathrm{L}(\$ 0.85 /$ gal) with a $16 \%$ surcharge added for lubricants and oil. The fuel consumption for the chain saw was derived from figures given by manufacturers: a 1.24-L (42 oz) fuel tank should give 25 minutes continuous cutting or about 60 minutes actual working time. Depending on the brand of saw, the gas-to-oil ratio is $16: 1$ or $32: 1$. With the cost of gas set at $\$ 0.26 / \mathrm{L}$ ( $\$ 1 /$ gallon), the cost of the fuel mixture would be $\$ 0.40$ to $\$ 0.50$; therefore we used the midvalue of $\$ 0.45 /$ hour. The cost per hour for fuel, repairs, and depreciation for equipment in the treatments was calculated from the information given above (Table 1).

\section{Results}

The cost of controlling western junipers ranged from $\$ 78 /$ ha $(\$ 31 /$ acre) for the use of picloram to $\$ 2,080 /$ ha $(\$ 832 /$ acre) for wood harvesting (Table 2 ). In considering these comparisons, one must remember that the treatments do not produce equal results. The proper application of picloram will kill the trees, but they will remain standing for many years. Usually, the density of trees prohibits the use of mechanical equipment to seed forage grasses in the environmental potential released by controlling the trees. The standing but dead trees are virtually fireproof and cannot be disposed of by burning. The herbicide and limb treatment was designed to either remove trees or cut the limbs from the trees so a rangeland drill could be towed among the dead trees for the seeding of forage species.

Both mechanical control and wood harvesting result in the complete removal of the trees. Wood harvesting leaves the stumps, whereas mechanical control extracts the stumps with the trees.

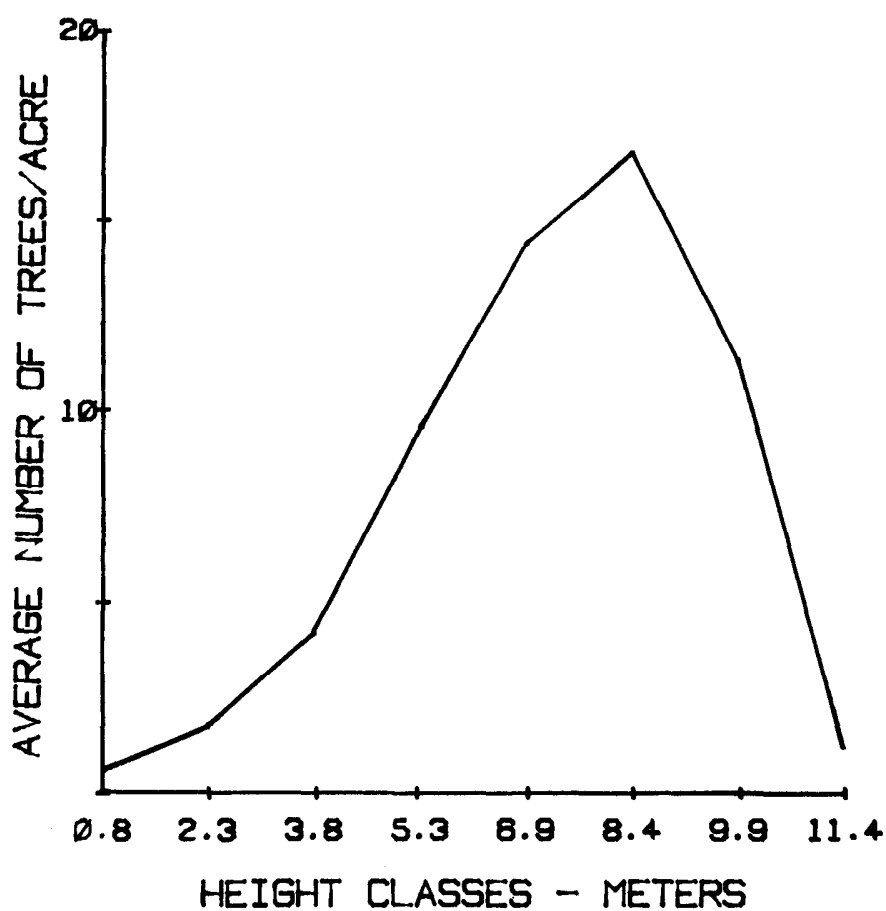

Fig. 1. Average number of trees per hectare by height classes for maturing stands of western juniper.

With both of these treatments, the site is ready for weed control and seedbed preparation. However, the product of wood harvesting helps offset the cost of the treatment.

We present the cost evaluation in relation to height classes of western juniper trees encountered in the treated woodlands. Costs per unit area were calculated by multiplying the average density of trees by the cost of treatment for a given height class. To a rrive at a cost analysis, the land manager who wishes to apply the results of the study only needs to know the density and height distribution of the trees in the woodland to be treated. Subdividing the stand of trees by height classes is also useful in designing the most effective multiple treatments for a given woodland.

The average western juniper stand to which we applied treatments had $52 \%$ of the trees in the 6.1 to $9.1 \mathrm{~m} \mathrm{(20-to} 30$-foot) height class (midvalues, 6.9 and $8.4 \mathrm{~m}$ or 22.5 and $27.5 \mathrm{ft}$ ) (Fig. 1). Only $2.4 \%$ of the trees in an average stand were shorter than $3 \mathrm{~m}$ ( 10 feet). This stand structure reflects sites that were rapidly invaded by junipers during the 1890's and through 1910 and since have been fully stocked with minimum chances for establishment of new trees (Young and Evans 1981).

\section{Picloram}

Because the rate of herbicide was based on the tree height, there was a positive relationship between the cost of picloram treatments and tree height (Fig. 2). However, this relationship was somewhat complicated by the inclusion of labor for applying the herbicide. It takes disproportionately longer to treat the dripline of large trees

Table 2. Cost per acre by tree height classes for western juniper control with picloram, control with picloram and limbing, mechanical control, and wood harvest. Tree height class distribution for average maturing stand of western juniper. ${ }^{a}$

Cost in dollars per acre

Midvalues of tree height class-ft

\begin{tabular}{|c|c|c|c|c|c|c|c|c|c|c|}
\hline Treatments & 2.5 & 7.5 & 12.5 & 17.5 & 22.5 & 27.5 & 32.5 & 37.5 & $\begin{array}{l}\text { Total cost/ } \\
\text { acre }\end{array}$ & $\begin{array}{l}\text { Total cost/ } \\
\text { hectare }\end{array}$ \\
\hline Picloram & 0.02 & 0.38 & 1.01 & 3.84 & 7.49 & 9.74 & 7.87 & 1.01 & 31.36 & 78.40 \\
\hline Picloram and limb & 0.46 & 2.82 & 3.87 & 17.43 & 46.10 & 57.29 & 45.64 & 60.30 & 179.64 & 449.10 \\
\hline Mechanical & 0.75 & 3.61 & 12.43 & 37.57 & 56.37 & 65.76 & 53.32 & 7.00 & 236.81 & 592.00 \\
\hline Wood harvest & 0.49 & 6.03 & 29.72 & 89.53 & 172.23 & 271.64 & 246.30 & 33.10 & 832.30 & 2080.75 \\
\hline
\end{tabular}

"For clarity only the total costs per acre are converted to metric system. 


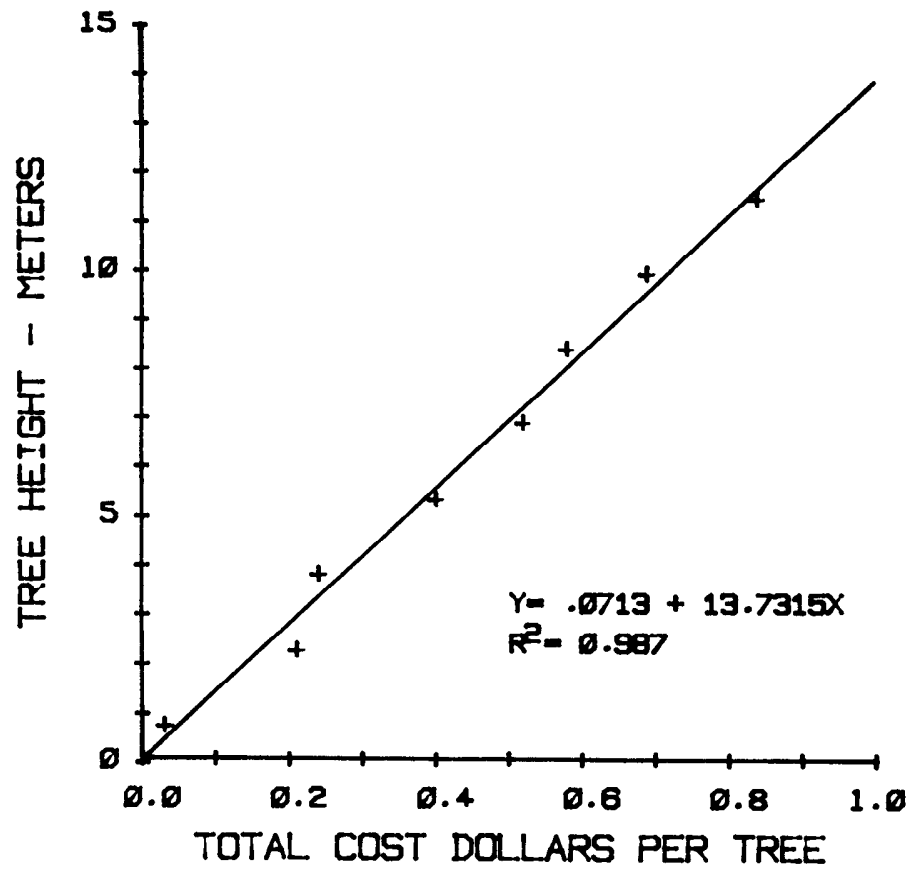

Fig. 2. Regression line, equation, and $\mathrm{r}^{2}$ value for relation between tree height and cost of application of picloram.

than that of small trees. As indicated by the coefficient of determination $\left(r^{2}=0.987\right)$, tree height accounted for $99 \%$ of the variability in the cost of controlling western juniper trees with picloram.

With dripline applications of picloram, 1 hour and 10 minutes labor was required to treat 0.4 ha $(1$ acre) of 60 trees with the average height distribution. Labor accounted for $19 \%$ of the $\$ 78 /$ ha ( $\$ 31 /$ acre) cost of the treatment (Fig. 3). Only $15.3 \mathrm{~kg} / \mathrm{ha}$ $(13.5 \mathrm{lb})$ were applied to an average acre of woodland; therefore, the additional cost of transporting the herbicide from the ranch headquarters to the site would be slight. With an $8-\mathrm{km}$ (5-mile) hauling distance and the truck we used for hauling wood in the evaluation, the cost of transporting the herbicide would be less than $\$ 0.03 /$ ha $(\$ 0.01 /$ acre $)$.

Table 3. Comparative labor requirements per acre in hours for picloram applications, picloram plus limbing, mechanical and wood harvesting operations for westem juniper woodlands. ${ }^{1}$

\begin{tabular}{lc}
\hline Treatment & $\begin{array}{c}\text { Time requirement } \\
\text { per acre } \\
\text { (hours) }\end{array}$ \\
\hline Picloram & 1.16 \\
Dripline & .75 \\
Undertree & .25 \\
Broadcast & \\
Picloram and limb & 1.16 \\
Dripline & 18.00 \\
Limbing & 2.00 \\
Slash disposal & 10.00 \\
Mechanical & \\
Wood harvest & 12.83 \\
Falling & 26.33 \\
Limbing & 16.63 \\
Bucking & 54.27 \\
Piling slash & 10.87 \\
Piling wood & 4.00 \\
Hauling wood & \\
\hline
\end{tabular}

'For clarity, the labor requirements are shown in hours per acre. To convert multiply by 2.5 hours per hectare.

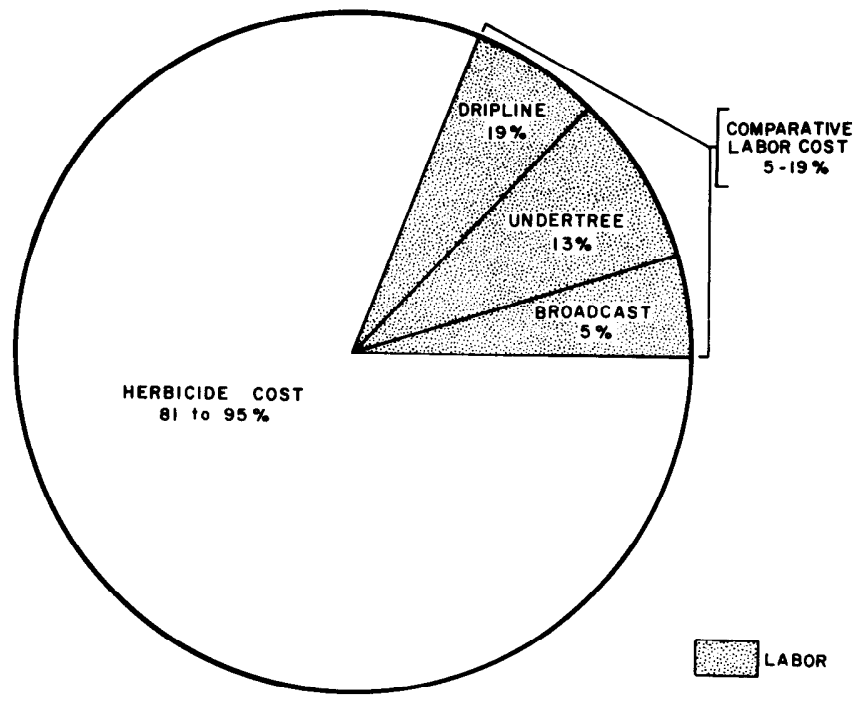

Fig. 3. Percentage distribution for cost involved in controlling western juniper trees with picloram. Three methods of application, dripline, under tree, and broadcast are compared. Labor costs are shaded. Total cost for dripline application is $\$ 78 /$ ha $(\$ 31 /$ acre).

We evaluated two other methods of applying picloram: under the tree and area broadcast. The efficiency of the tree control obtained with these three methods was equal in the specific stand treated (unpublished research, Agr. Res. Serv.-Reno, Nevada). The rate and, therefore, cost of herbicide was the same, but labor requirements differed (Table 3 ). By just throwing the required amount of herbicide under the trees and not worrying about distribution around the dripline, 0.4 ha ( 1 acre) of average woodland could be treated in 45 minutes, reducing the total cost per ha to $\$ 74$ $(\$ 29 /$ acre). If the herbicide was merely broadcast in the stand, at the same rate that would have been used to treat individual trees based on their height, labor requirements were reduced to 38 minutes/ha (15 minutes/acre) and the total cost reduced to $\$ 66 /$ ha (\$26/acre). This is a $19 \%$ reduction in cost per hecta re compared to the dripline treatment. With broadcast treatments only $5 \%$ of the total cost is labor.

In states where picloram is registered for control of western juniper on rangelands, the label specifies dripline treatment. The label also specifies $51 \mathrm{~g}$ of herbicide per $\mathrm{m}(2 \mathrm{oz}$ per yard) of tree height, four times the rate used in this evaluation.

\section{Picloram and Limb}

The herbicide and application remain the same for the picloram and limb treatment, but costs for limbing, labor, chain saw fuel, repairs, depreciation, and slash disposal must be added. The high correlation between tree height and total cost remains (Fig. 4), with $92 \%$ of the variability in cost being accounted for by tree height. The total cost jumps to $\$ 449$ (Table 2) or $\$ 370$ above the cost per hectare of picloram alone ( $\$ 179 /$ acre total cost). Of this additional, $\$ 115$ are chain saw expenses (fuel, repairs, and depreciation) and $\$ 255$ for labor (Table 3). Fifty hours/ha (20 hours/acre) additional labor above that required for herbicide application alone were required for limbing the trees. Limbing required $90 \%$ of the additional labor (Fig. 5).

The quality of the seedbed left by the picloram and limb treatment was highly variable. The spots where the slash was burned provide an excellent competition-free seedbed with no evidence of water repellency by the burned soil. The undisturbed accumulation of litter left under the canopies of the standing, but dead trees creates a very poor seedbed for many years until the litter decays.

\section{Mechanical Tree Removal}

The total cost for mechanical removal of the western juniper trees was $\$ 595 / \mathrm{ha}(\$ 236 /$ acre) for woodland with an average of 150 trees/ha (60 trees/acre). Tree height accounted for $93 \%$ of the 


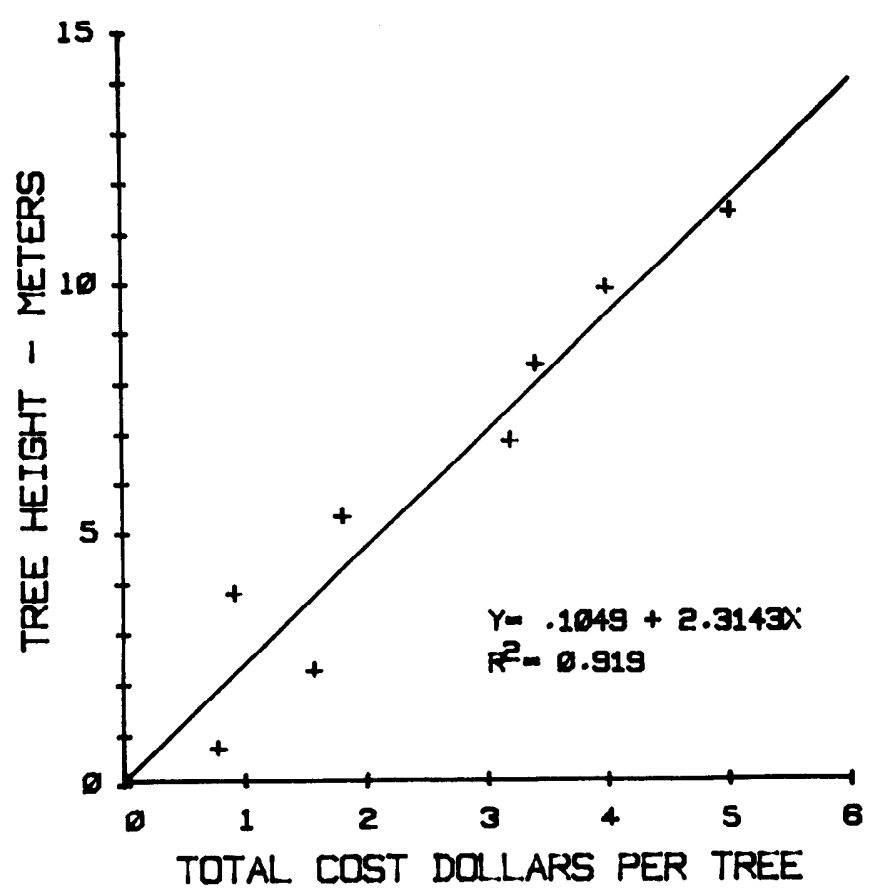

Fig. 4. Regression line, equation, and $\mathrm{r}^{2}$ value for relation between tree height and the cost of application of picloram and limbing trees.

variability in cost per tree (Fig. 6). In mechanical clearing, stand density has a proportionately larger influence on cost because of the time required to move the tractor from tree to tree. The major portion, $43 \%$, of the cost of mechanical clearing was in labor for tractor operation (Fig. 7). Because of the skill level required, we valued this labor at $\$ 10$ /hour, double the cost of the general skill labor. Tractor fuel and repairs were other major contributors to the cost of mechanical clearing. Because of the large capital investment in the tractor, depreciation becomes a major cost at $15 \%$ of the total. Slash disposal was a relatively minor cost of mechanical clearing, amounting to $3 \%$ of the total.

\section{Wood Harvest}

Tree harvesting for fuel wood was a labor-intensive treatment and is expensive at $\$ 2,080 /$ ha $(\$ 832 /$ acre). The correlation between tree height and cost per tree remained high, with $97 \%$ of the cost variability accounted for by tree height (Fig. 8). Labor accounted for $80 \%$ of the cost of this treatment (Fig. 9). Tree falling, limbing, and bucking and piling slash accounted for the major part of the required labor.

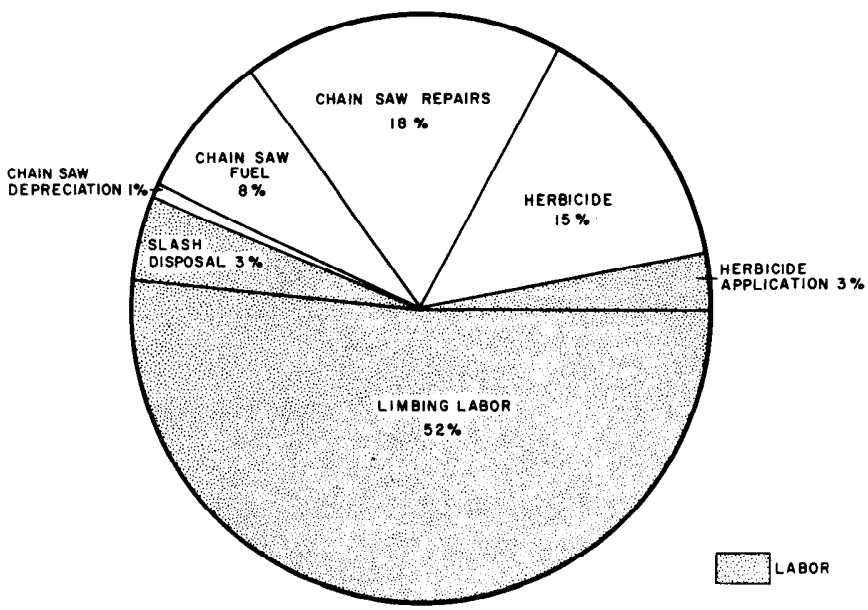

Fig. 5. Percentage distribution for cost involved in the picloram and limb treatment for control of western juniper trees. The labor costs are shaded. Total cost is $\$ 448 /$ ha $(\$ 179 /$ acre).

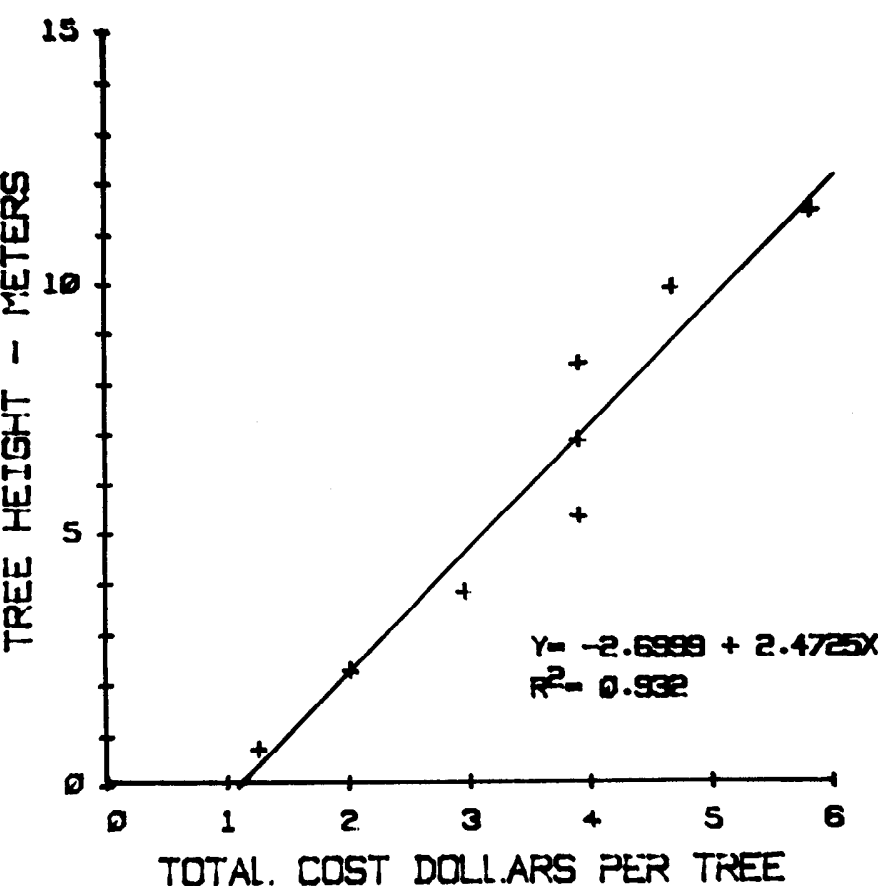

Fig. 6. Regression line, equation. and $\mathrm{r}^{2}$ value for relation between tree height and the cost of mechanically removing trees.

Tree harvesting leaves the stumps, but if the trees are cut at the soil surface, implements such as rangeland drills can be pulled over them. In contrast, mechanical clearing results in the tree rootballs being jerked from the ground. This results in holes that are too large for wheeled tractors to negotiate on $2 \%$ of the area, and $5 \%$ of the treated area is taken out of production by the piles of rootballs and trunk bases that will not burn.

Based on an average yield of $56 \mathrm{~m}^{3}$ of fuelwood per hectare ( 10 cords/acre), we harvested 442.5 million btu of energy from each hectare (177 million btu/acre) (Table 4). If the ranchers who own the woodlands were willing to use this wood in place of fuel oil, a replacement value of $\$ 4,525 / \mathrm{ha}(\$ 1,810 /$ acre) could be realized, with fuel oil at $\$ 0.26 / \mathrm{L}$ ( $\$ 1 /$ gallon). Note that our harvest costs were $\$ 2,080 /$ ha $(\$ 832 /$ acre), leaving a profit of $\$ 2,444 /$ ha (\$977/acre). This would be a considerable cash savings, but the rancher and his family would have to give up the convenience of oil heat for the constant attention and inconvenience associated with heating with wood as fuel.

More importantly, the rancher would have to have the time necessary to cut the wood. Because of weather constraints on other

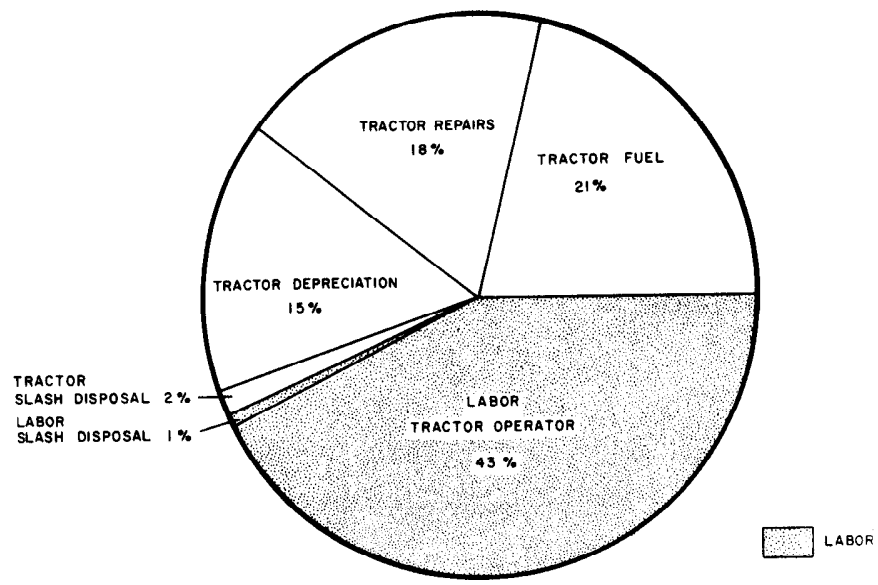

Fig. 7. Percentage distribution for cost involved in mechanical removal of western juniper trees. Labor costs are shaded. Total cost is $\$ 595 /$ ha (\$237/acre). 
Table 4. Wood yield from western juniper trees and its energy value compared to white oak and ponderosa pine. ${ }^{a}$

\begin{tabular}{|c|c|c|c|c|}
\hline Species comparison & $\begin{array}{l}\text { Available heat per } \\
\text { cord of wood (Btu's) }\end{array}$ & $\begin{array}{l}\text { Anthracite } \\
\text { coal (tons) }\end{array}$ & $\begin{array}{c}\text { Equivalent energy } \\
\text { Fuel oil } \\
\text { (gallons) } \\
\end{array}$ & $\begin{array}{l}\text { Natural gas } \\
\left(100 \mathrm{ft}^{3}\right)^{3}\end{array}$ \\
\hline White oak & 22.7 million & 1.04 & 232 & 284 \\
\hline Western juniper $78 \%$ of white oak & 17.7 million & .81 & 181 & 221 \\
\hline Ponderosa pine & 13.6 million & .62 & 139 & 170 \\
\hline $\begin{array}{l}\text { Average yield of juniper wood } \\
10 \text { cords } / \text { acre }\end{array}$ & 177 million & 8.10 & 1810 & 2210 \\
\hline
\end{tabular}

assuming 80 cubic feet $\left(2.24 \mathrm{M}^{3}\right)$ of solid wood per air-dry cord (12-15 percent moisture).

${ }^{\mathrm{b}}$ All comparisons in English units only for clarity. Energy values from Sargent (1885).

farming/ranching activities, the months of December, January, and February are about the only period when the typical rancher has time for wood harvesting. If, during this 3-month period, cattle are fed 2 hours/day and if two-thirds of the working days had suitable weather, the rancher would have 260 hours available for wood cutting. Each cord of wood required 12.4 hours of labor. With a 180-day home heating requirement in the western juniper area, the rancher would need $2,044 \mathrm{~L}$ ( 540 gallons) of fuel oil or $6.72 \mathrm{~m}^{3}$ (3 cords) of juniper wood annually. This is based on $11.36 \mathrm{~L}$ ( 3 gallons) per day consumption. The wood harvest would require 37 of the 260 available hours. Unfortunately, only 0.12 ha (onethird of an acre) would be cleared for range improvement yearly. If the rancher uses the wood harvest technique for range improvement and he wants to do a significant area of woodland annually, he has to have a market for the wood.

The average retail price of ponderosa pine (Pinus ponderosa) wood in the Reno, Nev., metropolitan area has been $\$ 95 / 2.24 \mathrm{~m}^{3}(1$ cord). Based on equivalent btu's, the price of western juniper wood in this market would be $\$ 115 / 2.24 \mathrm{~m}^{3}$ (1 cord) (Table 4). The rancher would have gross sales of $\$ 2,875 /$ ha $(\$ 1,150 /$ acre $)$ from selling juniper wood in the Reno market. Harvesting cost of $\$ 2,080 / \mathrm{ha}(\$ 832 / \mathrm{acre})$ would leave $\$ 31 / 2.24 \mathrm{~m}^{3}$ (1 cord) to pay for transportation and marketing cost. If the rancher could sell wood that was cut and yarded for $\$ 83 / 2.24 \mathrm{~m}^{3}$ ( 1 cord) to a commercial wood dealer in a central location, he would be breaking even while obtaining the site preparation for range improvement.

The shipping distance from the study area (Adin, Calif.) to the closest metropolitan market (Reno, Nev.) is $258 \mathrm{~km}$ (160 miles).

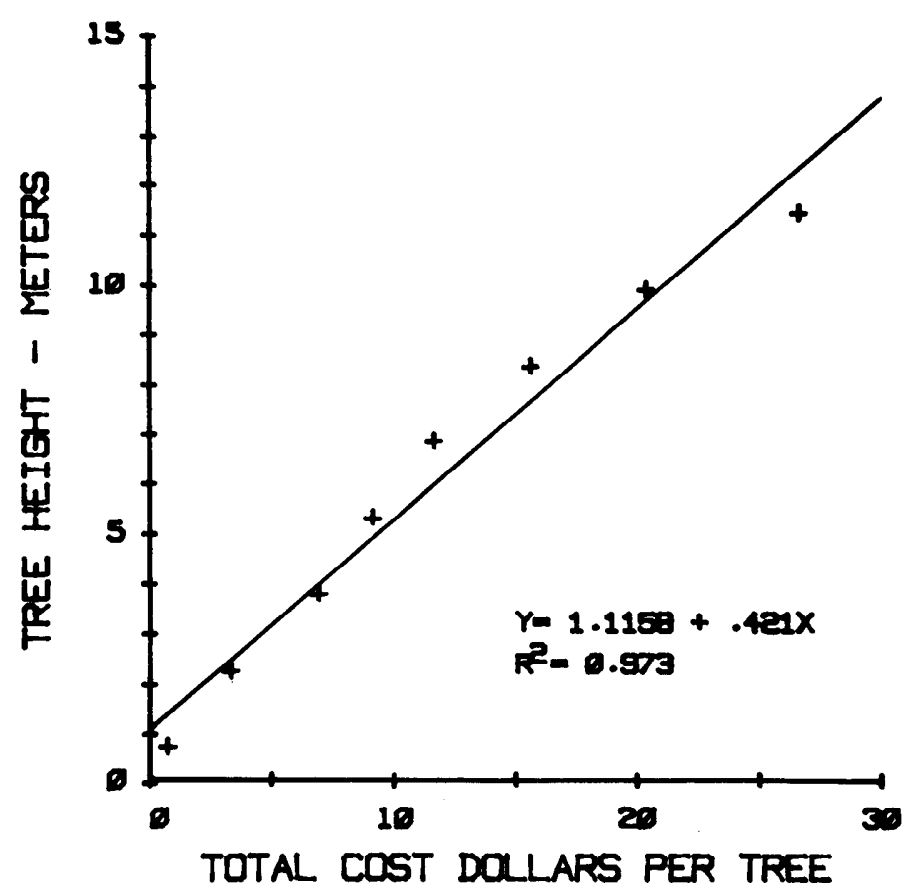

Fig. 8. Regression line, equation, and $\mathrm{r}^{2}$ value for relation between tree height and wood harvesting cost.
Based on 18-ton truckoads, the cost of shipping fuel wood would be $\$ 61 / 2.24 \mathrm{~m}^{3}$ (1 cord) with $1,419 \mathrm{~kg}(3,130 \mathrm{lbs})$ of air-dry wood per $2.24 \mathrm{~m}^{3}$ ( 1 cord). Without including loading, unloading, and retail delivery charges, this results in a net loss of $\$ 29 / 2.24 \mathrm{~m}^{3}$ (1 cord). Essentially, fuel wood prices will have to rise to at least $\$ 150 / 2.24 \mathrm{~m}^{3}$ ( 1 cord) in the Reno market for wood harvesting in the western juniper woodlands at Adin to be economically feasible.

\section{Discussion}

In this comparison of costs, methods ranged from the technologically intensive herbicide treatment where labor cost is $\$ 3.13 /$ ha (\$1.25/acre) to the labor-intensive treatment of wood harvesting where labor cost is $\$ 1,697 /$ ha $(\$ 679 /$ acre). When the ranchers choose among treatments for a specific woodland, they of ten fail to place a value on their own labor. Despite a lack of interest in the value of their labor, ranchers are always concerned with the amount of labor. Few ranchers have extra time to spend on range improvement, even in off-seasons from other ranch operations. Among the treatments evaluated, there are substantial differences in the amounts of labor involved. The herbicide treatment involves 38 minutes/ha (15 minutes/acre) while the wood harvest requires 303 hours/ha (121 hours/acre). If the rancher does not have the 303 hours/ha (121 hours/acre) to devote to wood harvesting and pursues this treatment with hired labor, the ranch operation faces a large cash outflow. The returns from wood harvest have no value for cash sales, only as a replacement for fuel oil. Once the rancher exceeds his own fuel requirements with replacement wood, he faces a stiff cash expenditure for labor with no return on his investment.

If a rancher in the western juniper area wants to substitute wood for oil as a source of household heat, he does not have to harvest juniper. Cull logs and pine slash are available from ponderosa pine logging operations, usually at no charge. It would require $8.96 \mathrm{~m}^{3}$

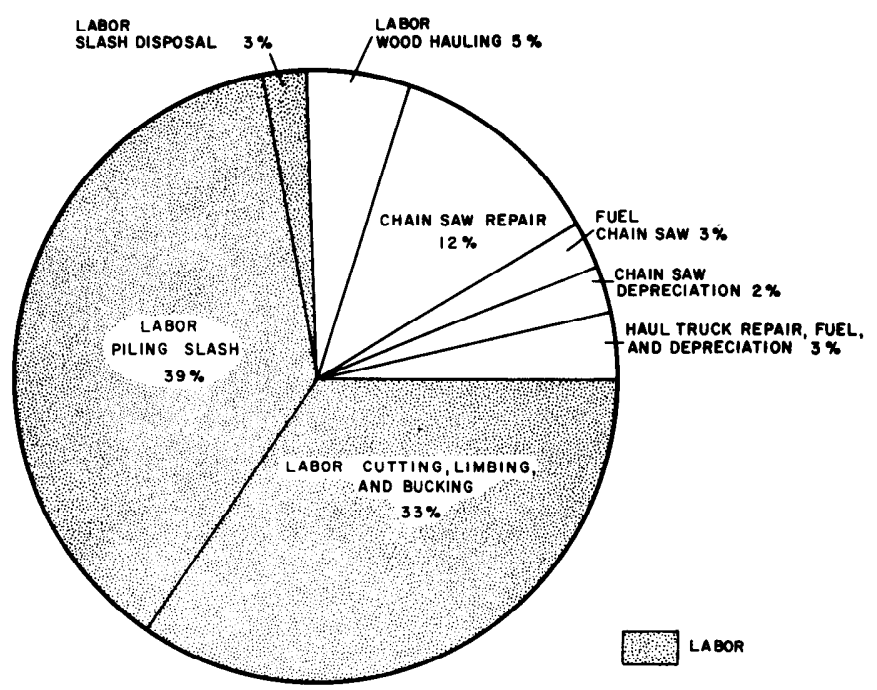

Fig. 9. Percentage distribution for cost involved in wood harvesting of western juniper trees. Labor costs are shaded. Total cost is $\$ 2,080 /$ ha (\$832/acre). 
( 4 cords) of pine to replace $6.72 \mathrm{~m}^{3}$ ( 3 cords) of juniper, but the labor requirements for cutting this wood would be reduced by two-thirds. No range improvement would result for the rancher's rangeland, but he would save money in energy costs.

Mechanical control of junipers offers a capital-intensive alternative to labor or technologically intensive treatments. A new 90-hp bulld ozer equipped track-layer tractor costs roughly $\$ 65,000$. We based this evaluation on used equipment with a replacement cost of $\$ 50,000$, but this is a large capital investment for generally capitalstarved ranchers. The cost of hiring a custom ope rator to carry out the mechanical treatments would probably be double the estimates we have made for rancher-owned and operated equipment. There is a tendency for ranchers to substitute older, used equipment for new expensive tractors. This reduces the capital requirements, but sharply increases repair costs. For the mechanical tree control, it costs $\$ 0.39 /$ minute to operate the tractor; $\$ 0.07$ or $18 \%$ of this cost is for repairs. The operation of track-layer equipment on rocky slopes leads to maintenance and repair costs that can rapidly multiply with older equipment.

In terms of fossil fuel cost per acre, mechanical clearing was $\$ 104 /$ ha $(\$ 43 /$ acre). The wood harvest used $\$ 83$ of fossil fuel per hectare ( $\$ 33 /$ acre); picloram and limb treatment used $\$ 33 /$ ha $(\$ 13 /$ acre).

The high cost of piling slash for disposal is readily apparent in the picloram and limb, and wood harvest treatments. Obviously, broadcast disposal of slash would be much cheaper. Unfortunately, we have found that the slash interferes with subsequent drilling operations, but does not carry a fire that will burn hot enough to consume the larger limbs. In wood harvesting from these woodlands, only about $42 \%$ of the entire woody biomass is marketed.

The possibilities for integrating treatments became readily apparent, especially for the smaller trees in the woodlands. Trees $2.3 \mathrm{~m}$ (7.5 feet) high cost \$2.01 to mechanically control, \$0.21 to kill with herbicides, or $\$ 1.57$ to control with the picloram and limb treatment. If mechanical control is used, it would be cheaper to spot treat the very small trees with picloram rather than push them over with the bulldozer.

It is worthwhile to again remind readers that not all the treatments produce equal results. The alternatives must be evaluated on the basis of their relative costs and the results they produce.

\section{Literature Cited}

Adams, A.W. 1975. A brief history of juniper and shrub populations in southern Oregon. Wildlife Res. Rep. No. 6. Oregon State Wildlife Commission, Corvallis, Ore., $33 \mathrm{p}$.

Burkhardt, J.W., and E.W. Tisdale. 1969. Nature and successional status of western juniper vegetation in Idaho. J. of Range Manage. 22:264-270.

Burkhardt, J.W., and E.W. Tisdale. 1976. Causes of juniper invasion in southwestern Idaho. Ecology 57:472-484.

Reed, A.D., and L.A. Herol. 1978. Farm machinery costs. Leaf. 2263. Div. Agr. Sci., Univ. of California, Davis. 19 p.

Sargout, C.S. 1885. Woods of the United States. Arnletend Co. New York. $320 \mathrm{p}$.

Young, J.A., and R.A. Evans. 1981. Demography and fire history of a western juniper stand. J. Range Manage. 34:501-506.

FOR INFORMATION

WRITE:

Dept. F.A.

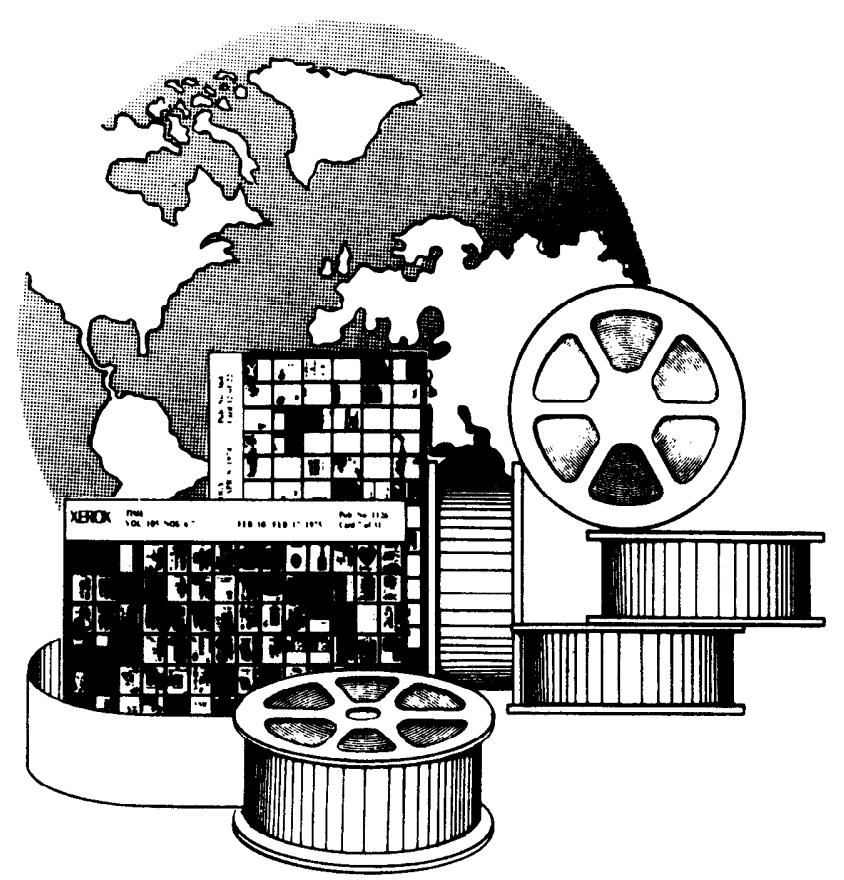

University Microfilms International

300 North ZeebRoad

18 Bedford Row

Ann Arbor, Mich. 48106

U.S.A.

London, WC1R 4EJ

England 